\title{
Article
}

\section{Transboundary Fisheries Management}

Zou, Keyuan and Wang, Jiayi

Available at http://clok.uclan.ac.uk/36193/

Zou, Keyuan ORCID: 0000-0002-2868-4948 and Wang, Jiayi ORCID: 00000003-2720-8218 (2020) Transboundary Fisheries Management. The Korean Journal of International and Comparative Law, 8 (2). pp. 101-130. ISSN 22134476

It is advisable to refer to the publisher's version if you intend to cite from the work. http://dx.doi.org/10.1163/22134484-12340134

For more information about UCLan's research in this area go to http://www.uclan.ac.uk/researchgroups/ and search for < name of research Group>.

For information about Research generally at UCLan please go to http://www.uclan.ac.uk/research/

All outputs in CLoK are protected by Intellectual Property Rights law, including Copyright law. Copyright, IPR and Moral Rights for the works on this site are retained by the individual authors and/or other copyright owners. Terms and conditions for use of this material are defined in the policies page.

\section{CLoK}

Central Lancashire online Knowledge www.clok.uclan.ac.uk

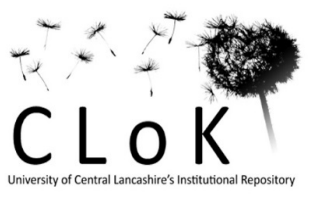




\section{Transboundary Fisheries Management: China's Practice}

\section{Keyuan Zou and Jiayi Wang}

\section{Introduction}

Fish is an important part of human diet, contributing $17 \%$ of the world population's intake of animal protein. ${ }^{1}$ Globally, the fish consumption rate has been growing faster than global population growth since $1961 .^{2}$ Although the global aquaculture production has been increasing rapidly since the late 1980s, bridging the impressive gap between supply and demand, the fish production is still unable to meet the human demand. The international community now faces a great challenge to get enough fish for a population in excess of 9 billion people by the middle of the twenty-first century. Since the aquaculture production has been increasing more slowly in recent decades, as compared to the high annual human growth rates in the1980s and 1990s, ${ }^{3}$ there are more pressures on capture fisheries. The global capture fisheries production reached 90.9 million tonnes in 2016, representing 53 percent of the total fish production, ${ }^{4}$ and it is forecasted that the number will be reaching more than 94 million tonnes in 2025 . According to the report revealed by FAO, marine catches constitute most of the capture fisheries production, presenting 87.2 of the global total. ${ }^{5}$ However, the status of fishery resources is in a worrisome situation. In 2015, 31.5 percent of fish stocks are fished at a biologically unsustainable level, three times that of 1974, while 59.9 percent of the species are fully fished. ${ }^{6}$ The marine ecosystems have been already under stress from climate change, pollution and habitat degradation, making the sustainable fisheries face more severe challenges. How to develop sustainable capture fisheries in economic, ecological and social dimensions is with great importance for the international

\footnotetext{
${ }^{1}$ Food and Agriculture Organization of the United Nations, The State of World Fisheries and Aquaculture 2018 Meeting the Sustainable Development Goals, FAO, Rome, 2018, p.13.

${ }^{2}$ See J.L. Anderson., F. Asche, T. Garlock, J. Chu, Aquaculture: Its role in the future of food, Frontiers of

Economics and Globalization, Vol.17, 2017, p. 160

${ }^{3}$ See supera note 1, p. 17.

${ }^{4}$ Ibid, pp.2-3.

${ }^{5}$ Ibid, pp.6-7.

${ }^{6}$ Ibid.
} 
community and needs a variety of cooperation among countries.

While cooperation is more urgent, it is also complicated in the management of transboundary fisheries. The United Nations Convention on the Law of the Sea (LOSC) created the exclusive economic zone (EEZ) regime, which makes more than $90 \%$ of the world's commercial fish stocks under the national jurisdiction of coastal states. ${ }^{7}$ The regulation of fisheries may vary among states due to different objectives in light of their own social and economic circumstances. However, the fish do not respect national boundaries, and the biological characteristic of the fish demonstrates that the long-term sustainability of fisheries can only be achieved through cooperation and coordination among states, especially for the conservation of straddling and highly migratory species. Despite many efforts made by regional fisheries management organizations (RFMOs), there has been slow progress in promoting effective and sustainable management of transboundary fisheries. The ocean may have more than 1,500 transboundary fish stocks, but only a limited number are subjected to effective cooperative management. ${ }^{8}$ For example, the high economic value species-Tuna, is highly migratory and often straddling distributed, and it is reported that 43 percent of the principal market tuna species were fished at biologically unsustainable levels in $2015 .{ }^{9}$ Thus, how to well manage transboundary fisheries is one of the most pressing issues on the way towards achieving long-term sustainable fisheries. This chapter aims to provide an overview of China's practice on transboundary fisheries management and to discuss the existing issues and future challenges China faces.

\section{The Nature and Social Conditions of China's Fisheries}

China is located in East Asia along the coastline of the west Pacific Ocean, bordering

\footnotetext{
${ }^{7}$ World Review of Highly Migratory Species and Straddling Stocks, FAO Fisheries Technical Paper, p.3. Available at www.fao.org/3/T3740E/T3740E00.htm\#TOC, last accessed 11 December 2019.

${ }^{8}$ FAO Fisheries Report No. 695, Supplement, Papers Presented at the Norway-FAO Expert Consultation on the Management of Shared Fish Stocks, Bergen, Norway, 7-10 October 2002, p.26. Available at http://ftp.fao.org/docrep/FAO/006/y4652e/y4652e00.pdf, last accessed 21 December 2019.

9 See N. Ramsden, FAO: States of World's Fisheries declining, 10 July 2018, available at https://www.undercurrentnews.com/2018/07/10/fao-state-of-worlds-fisheries-is-declining/, last accessed 25 December 2019.
} 
one internal sea, the Bohai Sea and three semi-enclosed seas, East China Sea, Yellow Sea and South China Sea. It has coastlines of more than 18,000 kilometers and island coastlines of 14,000 kilometers. ${ }^{10}$ The semi-closed nature of the waters makes China's transboundary fisheries management more difficult, since the fisheries sustainability requires a variety of cooperation between the surrounding coastal states. In the East China Sea and Yellow Sea, China shares fisheries resources with Japan, North Korea and South Korea. ${ }^{11}$ The situation in the South China Sea is even much more complicated, due to the factors not only because it is surrounded by China, the Philippines, Indonesia, Vietnam, Cambodia and Malaysia, but also most of the economic fish stocks in the South China Sea are straddling stocks. The introduction of the EEZ regime extended the jurisdiction of coastal states, but meanwhile, it brought new tensions. The overlapping claims exist both in the East China Sea and South China Sea and the complicated political relations create obstacles to the development of fisheries cooperation in these seas.

Besides the geographic setting, the socioeconomic circumstances of East Asian countries are quite different from countries in other regions. The East Asian countries have the high population density, with China, Japan and Korea accounting for 13 percent of the world population. With the decrease of terrestrial resources, marine fisheries are critical to ease the pressure from the population growth and promote economic development. The East Asian countries possess 3.5 million fishing vessels, accounting for 75 percent of the global fleet, and the fisheries industry plays a vital role in their national economies. China is the world's top fish producer and exporter, and in 2017 the total value of the fishery output was 1231.385 billion yuan, of which the output value of marine capture fishery was 198.765 billion yuan. ${ }^{12}$ Meanwhile, Vietnam and Thailand are also the major fish exporters, and Japan presented the third largest single market for fish and fish products. ${ }^{13}$ Those significant social and economic factors

\footnotetext{
${ }^{10}$ R. Blomeyer, I. Goulding, D. Pauly, A. Sanz, and S. Kim, The Role of China in World Fisheries, Directorate General for Internal Policies Department B: Structural and Cohesion Policies, 2012, p.12. Available at http.//www.europarl.europa.eu/studies, last accessed 25 December 2019

${ }^{11}$ Guifang Xue, China and International Fisheries Law and Policy, Martinus Nijhoff Publisher, 2005, p.79.

${ }^{12}$ China Fisheries Yearbook 2018(in Chinese), Beijing: China Agriculture Press, 2018, p.1.

${ }^{13}$ See supera note 1, p. 26.
} 
might cause the competitive exploitation of shared fish stocks and pose challenges to fisheries conservation and management. Although the management of transboundary fisheries has been a long-time challenge, China has taken steps trying to achieve the level of compliance with international standards.

\section{The International Legal Framework on Transboundary Fisheries}

The LOSC provides the duty of states to cooperate on transboundary fisheries according to the different characteristics of fish stocks. "Transboundary stocks" in a broad sense refers to any fish stocks that swim across jurisdictional boundaries of more than one state or between coastal states' EEZs and the high seas. ${ }^{14}$ Thus, it includes shared stocks, straddling stocks and high migratory species, and the LOSC provides the basic rights and obligations of states in respect of these stocks. ${ }^{15}$

\section{(1) Shared stocks}

Shared stocks refer to fish stocks shared by two or more coastal states whose EEZs are contiguous. According to Article 63(1) of the LOSC:

"Where the same stock or stocks of associated species occur within the exclusive economic zones of two or more coastal States, these States shall seek, either directly or through appropriate subregional or regional organizations, to agree upon the measures necessary to coordinate and ensure the conservation and development of such stocks. $" 16$

As to the states bordering an enclosed or semi-enclosed sea, the LOSC also requires the coastal states to take measures to coordinate the management, conservation, exploration of the shared stocks ${ }^{17}$ and to coordinate the implementation of the rights and duties with respect to the protection and preservation of the marine environment. ${ }^{18}$

Despite the requirements of cooperation and coordination on shared stocks under the

\footnotetext{
${ }^{14}$ E. Hey, The Regime for the Exploitation of Transboundary Marine Fisheries Resources, Dordrecht: Martinus Nijhoff Publishers, 1989, p.1.

${ }_{15}$ A.V. Houtte, Legal Aspects in the Management of Shared Fish Stocks-A Review, available at www.fao.org/3/Y4652E/y4652e04.htm\#bm04, last accessed 25 December 2019

${ }^{16}$ The LOSC, Article 63 (1).

${ }_{17}$ The LOSC, Article 123(a).

${ }^{18}$ The LOSC, Article 123(b).
} 
LOSC, in the absence of a compulsory obligation to reach agreement as well as of clear guidance as to how cooperation takes place, the management measures for shared stocks are effected through state practice.

In practice a variety of cooperative arrangements have been put in place. The arrangements present various forms and institutional structures. The management measures for shared stocks may take the form of a periodic arrangement negotiated under a pre-existing framework treaty, ${ }^{19}$ like the 1989 Agreement between Denmark, Iceland and Norway concerning the Capelin Stocks between Greenland, Iceland and Jan Mayen, ${ }^{20}$ or adopted by a general cooperation agreement on an ad hoc basis, like the 1982 Nauru Agreement concerning the Cooperation in the Management of Fisheries of Common Interest. ${ }^{21}$

As to the enclosed or semi-enclosed seas, a more common practice is the measures adopted by a regional fisheries organisation or taken by a bilateral commission set up especially for the management of shared stocks. China's practice is mainly on this approach, which will be discussed in detail in the following part.

\section{(2) Straddling and highly migratory stocks}

Straddling fish stocks and highly migratory stocks are both transboundary and occur on the high seas. ${ }^{22}$ The straddling fish stocks is a concept developed in recent years, which refers to fish stocks that move back and forth between in both, the EEZ of one or more states and the high seas. Article 63(2) of the LOSC provides a general provision that coastal states and states fishing for straddling fish stocks

"shall seek, either directly or through appropriate subregional or regional organizations, to agree upon measures necessary for the conservation of these stocks in the adjacent area."

\footnotetext{
${ }_{19}$ P. R. Churchill, and A.V. Lowe, The Law of the Sea (3rd Edition), Manchester: Manchester University Press, 1999, p.295.

${ }^{20}$ The agreement provides that the parties shall seek to agree on a total allowable catch (TAC) for capelin each year. If no agreement can be reached, Iceland is to set the TAC. The TAC is divided into fixed percentages - $78 \%$ to Iceland and $11 \%$ to each of the other two parties; annual consultations and negotiations are held to decide on unilateral/bilateral quota arrangements, licensing arrangements and other management measures.

${ }^{21}$ See supra note 19, p.296.

${ }^{22}$ T. Henriksen, G. Honneland, and A. Sydnes, Law and Politics in Ocean Governance: The UN Fish Stocks Agreement and Regional Fisheries Management Regime, Leiden: Martinus Nijhoff Publishers, 2006, p.14.
} 
However, this provision is lack of the substantive guidance as to how to address the potential conflicts arising from the allocation of catches between coastal states and high seas fishing states. ${ }^{23}$ This provision only requires them to take cooperative measures for conservation purposes in the high seas, but not in the EEZs. ${ }^{24}$ Although according to Article 116(2), the freedom of high seas is subject to the "rights and duties and the interests of coastal states", when applying to the straddling stocks, the situation became very complicated. It is difficult to clarify what are the "rights and duties and the interests of coastal states" while the stocks are on the high seas. ${ }^{25}$ In practice, coastal states may take measures to restrict the fishing for straddling fish stocks on the high seas, with the purpose of the long-term well-being of the stocks concerned.

As to the highly migratory stocks, Annex 1 of the LOSC listed those species which migrate considerable distance during their life cycle, crossing the EEZs of two or more states and the high seas. The rights and obligations of states in respect of highly migratory stocks differ from those in respect of the straddling stocks. For the management of straddling stocks, the states are obliged to take measures for conservation purposes only in the high seas, while under Article 64 of LOSC, the states shall cooperate to ensure conservation and promote the objective of optimum utilization of highly migratory stocks throughout the region, both in EEZs and the high seas. Thus, the conservation of highly migratory stocks requires more integrated measures and concerted efforts by all states involved in fishing.

The requirement in the LOSC is further affirmed by the 1995 Agreement for the Implementation of the Provisions of the United Nations Convention on the Law of the Sea Relating to the Conservation and Management of Straddling Fish Stocks and Highly Migratory Fish Stocks (the 1995 Agreement). The 1995 Agreement was concluded with the aim to address the shortcomings of the LOSC provision on the high seas, especially Article 63(2). ${ }^{26}$ It accords the RFMOs more authority and provides non-flag states enforcement. The obligations to conserve and cooperate were

\footnotetext{
${ }^{23}$ See supra note 19, p.305.

${ }^{24}$ Ibid.

${ }^{25}$ See supra note 15.

${ }^{26}$ Ibid, p. 11 .
} 
strengthened by the adoption of the precautionary approach.

Besides the above instruments, the Food and Agricultural Organization (FAO) also adopted the Code of Conduct for Responsible Fisheries, which requires all states to ensure sustainable exploitation of marine living resources and promote cooperation in fisheries management. For fish stocks are exploited by two or more states, the states involved should cooperate through the fisheries organization or arrangement to ensure the compatibility of management measures. ${ }^{27}$

\section{China's Fishery Management}

\section{(1) Legal instruments}

Fisheries Law of the People's Republic of China is the primary national law to regulate all fisheries-related activities. It was adopted in 1986 and amended in 2000 and 2004. The existing law provides a broad legislative framework for the management, conservation, and sustainable development of China's fisheries resources, and it contains some important management and conservation measures which are listed in Table 1.

Table 1: China's Management Measures for Capture Fisheries

\begin{tabular}{|l|l|}
\hline Type & Measures \\
\hline Input Control & $\begin{array}{l}\text { Fisheries license System } \\
\text { Minimum mesh size }\end{array}$ \\
\hline Output Control & $\begin{array}{l}\text { Total Allowable Catch system } \\
\text { Closed seasons } \\
\text { Closed zones for bottom trawling }\end{array}$ \\
\hline Technical Control & $\begin{array}{l}\text { Minimum mesh size of fishing nets } \\
\text { Minimum catch size of fishing targets } \\
\text { Ban of destructive fishing methods }\end{array}$ \\
\hline Economic Instruments & Fisheries resources protection fees \\
\hline
\end{tabular}

${ }^{27}$ Code of Conduct for Responsible Fisheries, Article 7.1.3 


\begin{tabular}{|l|l|}
\hline & $\begin{array}{l}\text { Fish stock damage compensation } \\
\text { Resource Fee Collection }\end{array}$ \\
\hline Distant water fisheries management & Application and approval system \\
& Annual examination system \\
& Fishing vessels and crew management \\
& system \\
\hline
\end{tabular}

Source: Shuolin Huang, and Yuru He, 'Management of China's capture fisheries: Review and prospect', Aquaculture and Fisheries 4 (2019), pp 173-182.

Although there are abundant regulations and management measures in place, they are not adequate to embrace the complexity of fishery management and some of the regulations are not properly implemented. It is criticized that the Fisheries Law has not adapted to the requirements of the current situation. ${ }^{28}$ For example, there are no relevant provisions related to the penalties of illegal fishing activities, increasing the difficulty of law enforcement. In addition, China's fisheries policy has been shifted towards a more ecological way since the 1990s. In 2006, the "Program of Action on the Conservation of Living Aquatic Resource of China" was promulgated by the Chinese government, which provides that " by 2020, the aquatic environment should be gradually rehabilitated, and catch from marine capture fisheries should generally accommodate the supporting ability of fishery resources." 29 It is suggested the Fisheries Law pay more attention to sustainable development of fisheries.

Thus, the revision of the Fisheries Law has received great attention and has been included in the work plans of the State Council and the National People's Congress, and it is currently under revision. In August 2019, the draft of the revised Fisheries Law was released to the public for consultation. ${ }^{30}$

\footnotetext{
${ }^{28}$ See Yukun Li, Ministry of Agriculture: the current fisheries law has not adapted to the new situation, and the revision has been included in the work plan(in Chinese), 25 October 2018, available at https://baijiahao.baidu.com/s?id=1615287830917762649\&wfr=spider\&for=pc, last accessed 25 December 2019.

${ }_{29}$ Program of Action on the Conservation of Living Aquatic Resource of China, Long-term goal, available at pkulaw.cn/fulltext_form.aspx?Gid=e80262bedf8dc8f20d5e7bff00d4b652bdfb, last accessed 25 December 2019.

${ }^{30}$ See 'The Fisheries Law is currently under the revised procedure' (in Chinese), 21 October 2019, available at ocean.china.com.cn/2019-10/21/content_75322543.htm, last accessed 25 December 2019.
} 
In the draft of the revised Fisheries Law, the closed season management system will be further refined, the corresponding legal responsibilities will be supplemented and improved, the penalty cost will be significantly increased, and the pertinence, operability and deterrence of the law will be enhanced.

Except the Fisheries Law, the Law on the Territorial Sea and the Contiguous Zone (1992 Territorial Sea Law $)^{31}$ and the Law on the Exclusive Economic Zone and Continental Shelf (1998 EEZ Law $)^{32}$ also have relevance to the fisheries management, especially to the management of shared stocks. According to the 1992 Territorial Sea Law, China possess the $12 \mathrm{~nm}$ territorial sea and $12 \mathrm{~nm}$ contiguous zone from the outer limit of the territorial sea. ${ }^{33}$ At the time that China ratified the LOSC, it proclaimed part of its straight baselines to measure its maritime zones. ${ }^{34}$ There is no specific provision related to fisheries in the 1992 Territorial Sea Law since China has full sovereignty to the territorial sea, and the fishing activities are subject to national fisheries laws and regulations.

Fishery management is an important part of the EEZ legislation. China proclaimed its EEZ in 1996 when China ratified the LOSC. ${ }^{35}$ The 1998 EEZ Law ensures China's sovereign rights and jurisdiction over its EEZ and continental shelf. According to the 1998 EEZ Law, China has sovereign rights in its EEZ for the purpose of exploring, conserving and managing the natural resources, and it has the right to take conservation and management measures to prevent the living resources in the EEZ from any harm of over-exploitation. ${ }^{36}$ This stipulation ensures that China has the right to conserve and manage transboundary species that originate in China. According to the LOSC, coastal state should determine its allowable catch in the EEZ, and if the coastal state does not

\footnotetext{
${ }^{31}$ The Law on the Territorial Sea and the Contiguous Zone was promulgated on 25 February 1992. Text in English is available at www.asianlii.org/cn/legis/cen/laws/lotprocottsatcz739/, last accessed 25 December 2019.

${ }_{32}$ The Law on the Exclusive Economic Zone and Continental Shelf was adopted on 26 June 1998. Text in English is available at www.lawinfochina.com/display.aspx?lib=law\&id=1767, last accessed 25 December 2019.

${ }_{33} 1992$ Territorial Sea Law, Article 3.

${ }^{34}$ The baselines for the mainland are from Shandong Peninsular to Hainan Island, and baselines are decided for the Xisha Islands (Paracel Islands), for details on this, see Keyuan Zou, 'Sino-Japanese joint fishery management in the East China Sea', Marine Policy, Vol. 27, 2003, pp.130-131.

${ }^{35}$ Keyuan Zou, 'China's exclusive economic zone and continental shelf: developments, problems, and prospects', Marine Policy, Vol.25, 2001, p.73.

${ }^{36} 1998$ EEZ Law, Article 6.
} 
have the capacity to harvest all the allowable catch, it should allow other states to get the surplus of the allowable catch. ${ }^{37}$ However, the 1998 EEZ law does not contain any provision regarding the surplus of allowable catch. The reason may be that there is no surplus left due to the overexploitation. Even so, the law does not prohibit foreign fishing in China's EEZ. Foreign fishing in China's EEZ needs to get a permit from the Chinese authorities. ${ }^{38}$ China has the right to take measures, such as boarding, inspection and arrest to ensure the foreign fishing to comply with Chinese laws and regulations. ${ }^{39}$

\section{(2) Institutional arrangements}

Fisheries management falls under the responsibility of the Bureau of Fisheries of Ministry of Agriculture (MOA), which is the highest fisheries authority in China. Its main function is to administer fishery sector, put forward development strategies on fisheries, draft related laws, draw up measures for the protection of fishery resources, administer the permits of fishing boats, and coordinate fishing activities nationwide. ${ }^{40}$ In order to ensure the rationality of fisheries management policy, the MOA has a governmental scientific institution-the Chinese Academy of Fishery Sciences, ${ }^{41}$ which provides technical support and makes policy recommendations.

It should be noted that China has implemented the plan for the reform of the ministerial structure since March 2018. Under the reform, the inspection, supervision and management of fishing vessels is now within the responsibility of the Ministry of Transport. ${ }^{42}$ In addition, the Ministry of Natural Resources is responsible for the management of the marine protected areas, which include the areas where fishing activities are prohibited or restricted. ${ }^{43}$ The new institutional structure will inevitably

\footnotetext{
${ }^{37}$ The LOSC, Article 62(2).

${ }^{38} 1998$ EEZ Law, Article 5.

39 1998 EEZ Law, Article 12.

${ }^{40}$ The main functions of Bureau of Fisheries are listed on the official website of Ministry of Agriculture, available at english.agri.gov.cn/aboutmoa/departments/201301/t20130115_9518.htm, last accessed 25 December 2019.

${ }^{41}$ Chinese Academy of Fishery Sciences is a subordinate institution of MOA, see english.agri.gov.cn/aboutmoa/ium/, last accessed 25 December 2019.

${ }^{42}$ See the Chinese Communist Party Central Committee, Plan on Deepening Reform of Party and State Institutions, available at http://www.scopsr.gov.cn/zxdd/zdxw/201803/t20180321_305088.html; accessed 16 December 2019.

${ }^{43}$ Ibid.
} 
create challenges to fisheries management since the effective and successful management calls for cooperation and coordination among different governmental authorities.

To ensure the enforcement of fisheries laws and regulations, three coastal fisheries management bureaus were established at the regional level. They are the Bureau of Yellow Sea and Bohai Bay, Bureau of East China Sea and Bureau of South China Sea. There are also local fisheries bureaus at coastal provinces and municipal local fisheries authorities.

\section{China's Practice on the Management of Shared Stocks}

China is a country bordering semi-enclosed seas, where EEZ claims overlap, which makes the management of shared stocks extremely important and complicated. Semienclosed seas are separated from oceans by narrow straits; thus, they are more vulnerable to human activities. ${ }^{44}$ The Yellow Sea, the East China Sea and the South China Sea are of dense biodiversity and high bio-productivity, the sustainability and conservation of species in these areas is important for the world fisheries. In addition, the fish stocks in the semi-closed seas usually migrate across the national boundaries for spawning, breeding and feeding. ${ }^{45}$ Hence, collective actions with the purpose of the conservation of shared stocks become imperative, even in the sea areas where conflicting territorial claims are pending. With the efforts of many years, China has promoted cooperative management for the shared stocks through bilateral fisheries agreements.

\section{(1) Management of Shared Stocks in the East China Sea and Yellow Sea}

In the East China Sea and Yellow Sea, China fulfill its obligations of cooperation by signing bilateral fisheries agreements with Japan and Korea respectively.

The efforts of joint fishery management between China and Japan can be traced back to 1955 , and it has gone through three main stages of development by three bilateral

\footnotetext{
${ }^{44}$ See supera note 11, p. 175.

${ }^{45}$ Guifang Xue, 'Bilateral Fisheries Agreements for the Cooperative Management of the Shared Resources of the China Seas: A Note’, Ocean Development and International Law, Vol.36, 2005, p.371.
} 
agreements. In June 1955, the first (non-governmental) fishery agreement was reached between the Japan-China Fisheries Council the China Fisheries Association and played a vital role in developing fishery relations between China and Japan. ${ }^{46}$ The second agreement was signed and came into force in 1975. Although the 1975 agreement was largely the same as the previous one, including six conservation zones and seven fishing closed zones, ${ }^{47}$ it first established a joint fishery committee, ensuring to better implement the agreement as well as to promote the conservation of fisheries resources in a harmonious way. After the adoption of the LOSC, the EEZs regime created more challenges to the fishery relations of the two countries, and it inevitably needed a new adjustment. Thus, after several rounds of negotiations, China and Japan signed a new fisheries agreement in 1997 (Sino-Japan Fishery Agreement), ${ }^{48}$ in which the conservation of shared stocks is one of the primary matters.

China and Korea shared the fishery resources in the Yellow Sea and the north part of the East China Sea. The joint efforts to conserve the shared stocks are based on the Agreement on Fisheries between the People's Republic of China and the Republic of Korea (Sino-Korean Fishery Agreement), which was signed in 2000 and became effective in 2001.

The two agreements provide similar frameworks and approaches to managing shared stocks in the following aspects:

Firstly, the two agreements adopted general principles to strengthen bilateral cooperation including the principle of conserving marine living resources of common concern and the principle of reciprocity. The contracting parties commit to cooperate to conserve marine living resources and adopt necessary measures to ensure their nationals and fishing boats comply with the conservation measures. The nationals and fishing boats of both sides have the right to fish in each other's EEZs based on the principle of reciprocity. However, the fishing boats of each party should obtain a fishing permit of

\footnotetext{
${ }^{46}$ Keyuan Zou, 'Sino-Japanese joint fishery management in the East China Sea', Marine Policy, Vol. 27, 2003, p. 126.

${ }^{47}$ Ibid, p. 127.

${ }^{48}$ Sino-Japan Fishery Agreement came into force in June 2000.
} 
the other party's competent authority, ${ }^{49}$ and fishery activities in the other's EEZ must comply with the agreements and the other's domestic law and regulations. ${ }^{50}$ The two agreements set forth the conditions under which arrest or detention is allowed.

Secondly, the Joint Fishery Committee (JFC) was established to ensure the effectively cooperation. The JFC plays key roles in cooperative management of shared fisheries resources. It has the power to make recommendations on the conservation and management measures, including the catch of fishery species, allocation of fishing quotas and other specific conditions for fishing in the other Party. Recommendation is subject to the unanimous consent of the committee members, and both sides should comply with the recommendations and adopted necessary measures in accordance with the decision. ${ }^{51}$

In addition, in the areas where EEZ claims of the two parties overlap, a Provisional Measures Zone (PMZ) was established. Under the Sino-Japan Fishery Agreement, the PMZ is located between the parallels of $27^{\circ} \mathrm{N}$ and Lat. $30^{\circ} 40^{\prime} \mathrm{N}$, and in the middle of the East China sea, $52 \mathrm{~nm}$ from the baseline of the territorial seas for the Chinese mainland coast, while the Sino-Korea Fishery Agreement sets up a PMZ between the parallels of $32^{\circ} 11^{\prime} \mathrm{N}$ and Lat. $37^{\circ} \mathrm{N}$, in the middle of Yellow Sea (See Figure 1). In the PMZs, The JMC has the responsibility to take into account each party's resource conditions, national catch capability as well as the traditional fishery activities to decide on the appropriate management measures, especially the total amount of fishing quotas apply to the PMZ. After years of practice, the two JFCs have developed various measures to achieve the conservation purpose. For example, the joint patrols of vessels were conducted in the China-Korea PMZ, which have significant effect on cracking down the illegal fishing, and the latest joint patrol was launched by the end of 2019.52 To ensure the conservation measure based on scientific information, the China-Korea Expert Group Meeting is convened regularly to exchange information on the implementation of the resource survey on the PMZ, and to report the findings of

\footnotetext{
${ }^{49}$ Sino-Japan Fishery Agreement, Article 2; Sino-Korean Fishery Agreement, Article 2.

${ }^{50}$ Sino-Japanese Fishery Agreement, Article 4; Sino-Korean Fishery Agreement, Article 4.

${ }^{51}$ Sino-Japanese Fishery Agreement, Article 11(4), Sino-Korean Agreement, Article 13(4).

${ }^{52}$ See www.yyj.moa.gov.cn/gzdt/201904/t20190418 6196075.htm, last accessed 11 October 2019.
} 
respective surveys to the JFC. ${ }^{53}$ In the China-Japan PMZ, China and Japan set target values for catches of different fishery species and count the catches according to the ways of operation and species respectively, and the JFC determines annually the target values of each country, based on the catch reports and the fishery status of the two sides. ${ }^{54}$ China and Japan also need to exchange the lists of each party's nationals and fishing vessels that fishing in the PMZ, and notify each other the regulations related to the operating modes recorded in the roster.

Figure 1: Provisional Zones of Sino-Japan/Sino-Korean Fisheries Agreements

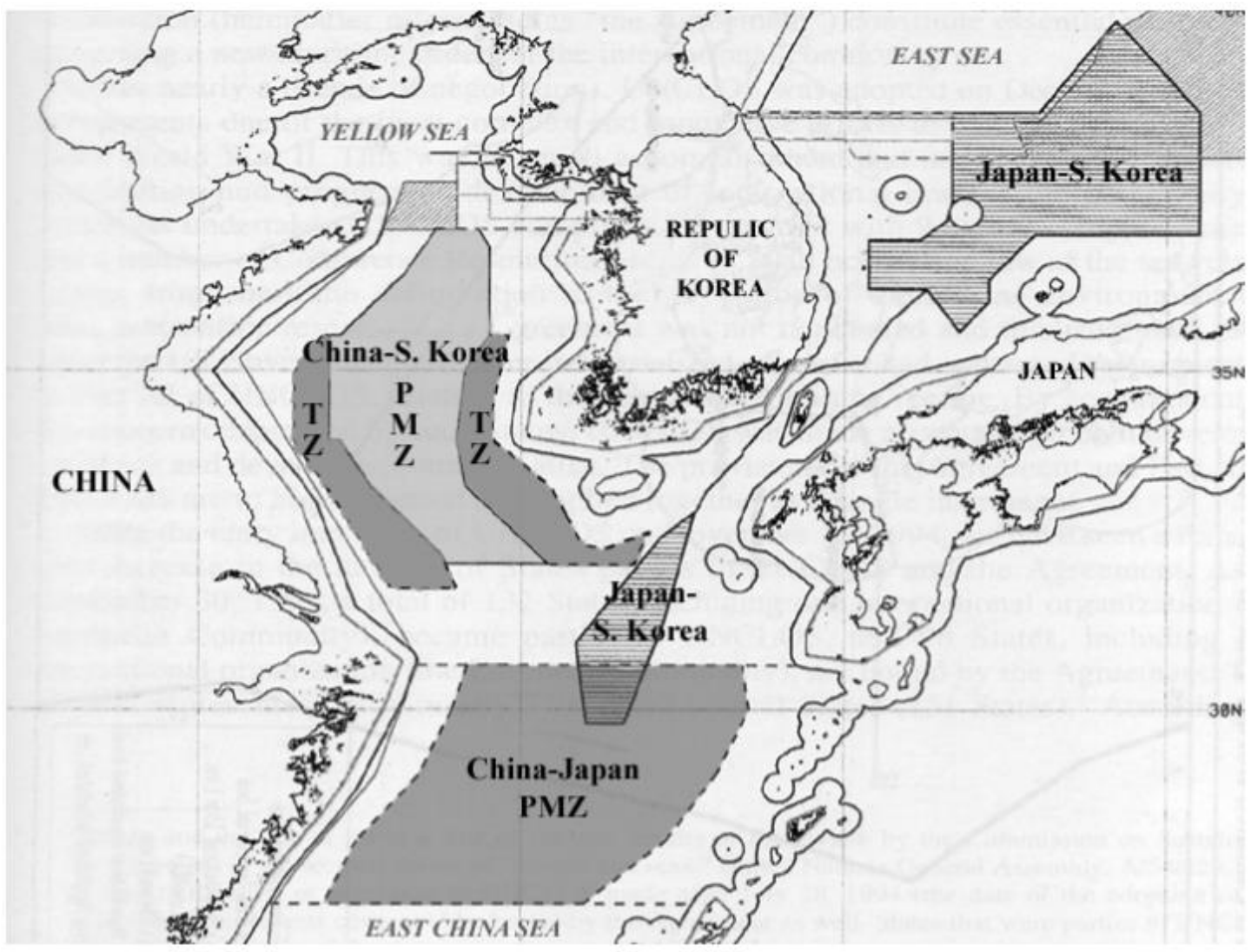

Source: Guifang Xue, 'Bilateral Fisheries Agreements for the Cooperative Management of the Shared Resources of the China Seas: A Note', Ocean Development and International Law, Vol.36, 2005, p.370.

To better implement the management measures, the flag state jurisdiction applies in the PMZ, which allows the detention of fishing vessels in case of any violation of

\footnotetext{
${ }^{53}$ See www.moa.gov.cn/govpublic/YYJ/201411/t20141104 4125427.htm, last accessed 11 October 2019.

${ }^{54}$ See www.moa.gov.cn/govpublic/YYJ/201502/t20150203 4392655.htm, last accessed 11 October 2019.
} 
operation conditions by the other party. The party, with due regard to notification, should inform the other party of the related details and the result after necessary measures have been taken. ${ }^{55}$ Thus, the regime applied to PMZs, created a sustainable fishing order in the undelimited maritime areas so as to protect the shared resources from the harm of overexploited.

The two agreements have created a mechanism of fishery cooperation for the management of shared stocks despite some complex political factors, and it can be regarded as important pioneering efforts made by China to fulfill relevant international obligation. However, from a resource management perspective, it also has some limitations.

Firstly, the management measures of shared stocks are not based on an ecosystem approach. Although the large common fishery zones were established, they only cover part of the East China Sea. Unregulated water exists in the two agreement. For example, the territorial waters of the Diaoyu/Senkaku Islands, where fishing activities are not regulated. However, many fish stocks migrate seasonally from the PMZ to the unregulated waters, and the effects of fishery conservation might be greatly compromised by the fishing activities in the unregulated waters. In addition to the problem of unregulated areas, bilateral allocation was not capable of dealing with shared stocks in a biological way. Almost all fish stocks in the East China Sea migrate beyond any one state, ${ }^{56}$ thus the two-player model of management cannot cover the whole migratory range of the fish stocks. The effective conservation requires the cooperation of all interested countries. Since the bilateral agreement cannot regulate the fishing activities of a third party, there is an urgent need to reach a regional or multilateral fishery arrangement of shared stocks in the East China Sea.

Secondly, although the two agreements allowed for cooperative management in the PMZs, they did not provide for cooperative management of stocks that migrated between the respective fishery zones, and there is a lack of dispute settlement

\footnotetext{
${ }_{55}$ Sino-Japanese Fishery Agreement, Article 7.

${ }^{56}$ Guifang Xue, 'Bilateral Fisheries Agreements for the Cooperative Management of the Shared Resources of the China Seas: A Note', Ocean Development and International Law, Vol.36, 2005, p.376.
} 
procedures to deal with the disagreements on management issues. Even in the PMZs, the JFCs have the power to decide the allocation of fishing quotas, but fail to consider the migratory characteristics of fish stocks. There are lots of migratory species in the East China sea and the Yellow sea, and some are commercially harvested by China, Korea and Japan. In order to prevent overfishing, it is reasonable to facilitate cooperative management of transboundary resources. There are plenty of successful examples in state practice to manage shared stocks. Canada and US signed the USCanada Pacific Hake Agreement to jointly manage the transboundary stock of Pacific hake. ${ }^{57}$ Under the Agreement, the total allowable catch (TAC) is decided jointly, with the input from both scientific advisory panels and consultation with the Industry Advisory Panel. ${ }^{58}$ In the East China sea and the Yellow sea, multilateral fishery arrangement should also be placed between the different countries sharing access to a commercially transboundary fish stock.

In addition, the two agreements are insufficient to deal with illegal, unreported and unregulated (IUU) fishing. In recent years, conflicts over IUU fishing intensifies between Chinese fishmen and Korea Coast Guard (KCG). In 2014, a Chinese fishing boat captain was killed by KCG due to resisting an inspection. ${ }^{59}$ On 1 November 2016, two Chinse boats were shots fired by the KCG. ${ }^{60}$ On 4 January 2018, the KCG used individual weapons and crew-served weapons against Chinese fishmen. ${ }^{61}$ These incidents reflect that tensions in regard to EEZ fishing has been growing in the Yellow Sea due to Korea's stricter law enforcement. To make the use of force against IUU fishing lawful, the KCG promulgated a new internal rules-Manual on the Use of Weapon on 8 November 2016 and the Maritime Security Act was amended on 18 April

\footnotetext{
${ }^{57}$ The US-Canada Pacific Hake Agreement was ratified in 2003, but formally implemented in 2012.

${ }^{58}$ M. Bailey, G. Ishimura, R. Paisley, and U.R. Sumaila, 'Moving beyond catch in allocation approaches for internationally shared fish stocks', Marine Policy, Vol.40, 2013, p.127.

59 'South Korean coast guard kills Chinese boat captain', 10 October 2014, available at https://www.militarytimes.com/news/your-military/2014/10/10/south-korean-coast-guard-kills-chinese-boatcaptain/, last accessed 25 December 2019.

${ }_{60}$ L. Collins, 'Is South Korea's use of force against Chinese Fishing Vessel illegal?', available at https://amti.csis.org/rok-force-chinese-vessels-illegal/, last accessed 25 December 2019.

${ }^{61}$ H.J. Kim, 'South Korea's use of force against Chinese illegal fishing in the course of law enforcement in the Yellow Sea', Marine Policy, Vol. 99, 2019, p.150.
} 
2017 to settle the procedure for the use of weapons throughout law enforcement. ${ }^{62}$ It is obvious that use of force is not an appropriate way to settle down the issue of IUU fishing, the two states should find a peaceful way to deal with this problem. There are several reasons that contribute to the IUU fishing in the Korea's territorial waters or EEZ. First of all, the maritime demarcation is still unsolved which makes the fisheries arrangement rather vulnerable. The coastal states may strengthen their jurisdiction by exercising fishery rights, in order to take advantage in the negotiation of maritime delimitation. Secondly, the allocation of fishery resources is unbalanced. The waters near South Korea is the main feeding ground and wintering area for fish stocks; as a result, the fishery resources are much richer in comparison with which in the waters near China. ${ }^{63}$ However, the government of South Korea over the past decade has taken steps to reduce the number of the fishing vessels with the aim of conservation of fishery resources. ${ }^{64}$ Consequently, the number of vessels that were permitted to fishing in the EEZ of South Korea was declined, which possess a dramatic challenge to Chinese fishmen. Moreover, the complicated issue of the Northern Limit Line (NLL) between the South Korea and North Korea has been recognized as a contributing factor to IUU fishing. It was reported that Chinese fishmen take advantage of the fishing contracts with North Korea and then illegally cross the NLL to fish in the South Korean waters. ${ }^{65}$ The long-standing fishery conflicts between China and Korea shows that there are still significant gaps in the Sino-Korea Fishery Agreement. The two parties should maintain peaceful fisheries by reaching a consensus on dispute settlement and promoting the establishment of fishery cooperation and law enforcement mechanism.

Finally, both the Sino-Japanese Fishery Agreement and Sino-Korean Fishery Agreement fail to address the issue of third party's interests. The fishery arrangements in the East China Sea and the Yellow Sea are very complex due to the overlapping

\footnotetext{
${ }^{62}$ Ibid, p. 148.

${ }^{63}$ Duo Ding, The implications and solutions of fishery disputes between China and South Korea (in Chinese), 2 April 2019, available at www.nanhai.org.cn/review_c/355.html, last accessed 25 December 2019.

${ }^{64}$ S.K. Kim, 'Illegal Chinese Fishing in the Yellow Sea: A Korean Officer's Perspective', Journal of East Asia and International Law, Vol.2, 2012, p. 472

${ }^{65}$ _L. Collins, ' Between a Rock and Grey Zone: China-ROK illegal fishing disputes', 6 July 2016, available at https://amti.csis.org/rock-grey-zone-china-rok-illegal-fishing-disputes/, last accessed 25 December 2019.
} 
jurisdictions of China, Japan and Korea. The third party's interests may be affected by any bilateral fishery arrangements concluded by the other two states. However, Korea is not satisfied with the northern limit line of the common fishery zone of Sino-Japanese Fishery Agreement, while China claimed that the Japan-Korea Fishery Agreement encroached on China's sovereign rights over its EEZ. ${ }^{66}$ In spite of this, one survey revealed that there are overlapping areas of China-Japan-Korea Fisheries Agreements (See Figure 2). ${ }^{67}$ The potential conflicts may arise due to the interplay between the various bilateral fishery agreements, and to make matters worse, Japan signed a fishery agreement with Taiwan on fishing rights in the disputed area-Diaoyu Islands in 2013. The complex political situation and increasing fishery conflicts make the current fishery arrangements in the East China Sea problematic, and a multilateral fishery arrangement is needed to pursuit a secured legal order in the East China Sea.

Figure 2: The overlapping areas of the China-Japan-Korea Fisheries Agreements

\footnotetext{
${ }^{66}$ See supera note 45, p. 137.

${ }^{67}$ For details on this issue, see Seokwoo Lee, Y.K. Park, and Hansan Park, 'The complex legal status of the Current Fishing Pattern Zone in the East China Sea', Marine Policy, Vol.81, 2017, pp.219-228.
} 


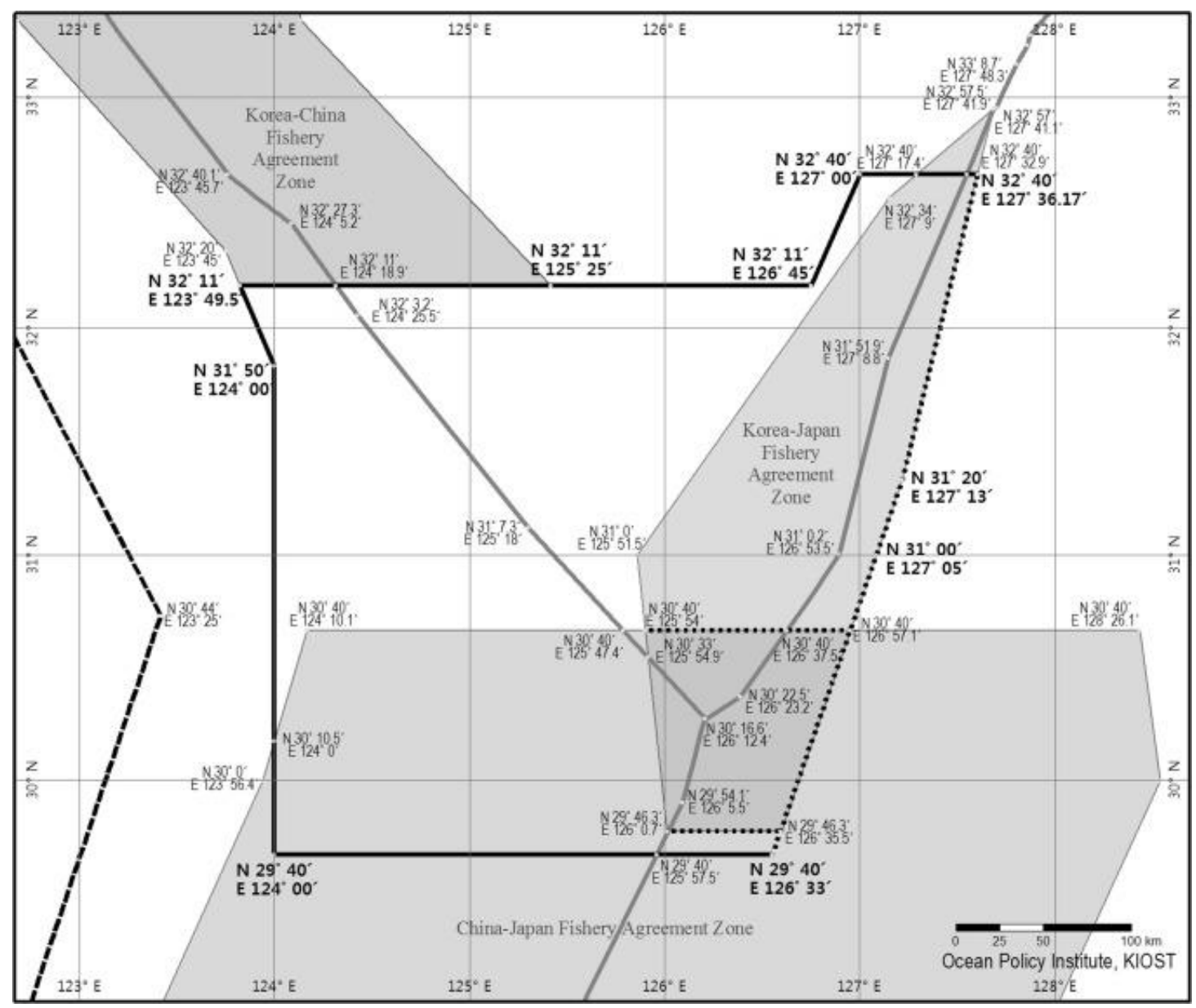

Source: Seokwoo Lee, Young Kil Park, and Hansan Park, 'The complex legal status of the Current Fishing Pattern Zone in the East China Sea', Marine Policy, Vol.81, 2017, p.221, Figure 2.

\section{(2) Management of Shared Stocks in the Gulf of Tonkin and the South China Sea}

The South China Sea, as a semi-enclosed sea, is situated at Southeast Asia, with an area of 648,000 square nautical miles ${ }^{68}$ and it connects to the East China Sea via the Taiwan Strait. The political and legal situation of the South China Sea is very complicated, since there are overlapping claims of sovereignty, overlapping claims to maritime zones and disputes over resources utilization. ${ }^{69}$ The rising tensions in this region have attracted the attention of the world community in the past decades, and also make fisheries management more difficult.

The South China Sea is of strategic importance to all the adjacent countries, not only

\footnotetext{
${ }^{68}$ J.R.V. Prescott, The Maritime Political Boundaries of the World, Methuen London, 1985, p. 209.

${ }^{69}$ Keyuan Zou, 'The Chinese Traditional Maritime Boundary Line in the South China Sea and Its Legal Consequences for the Resolution of the Dispute over the Spratly Islands', The International Journal of Maritime and Coastal Law, Vol.14, No.1, 1999, P.30.
} 
it contains a critical sea route for international trade, but also for its abundant marine resources and rich biodiversity. An investigation in the year of 2000 shows that a total of 3,365 species of fishes in 263 families are recorded from South China Sea. ${ }^{70}$ However, with the development of fishing activities and growing competitions for the limited fish stocks, the fishery resources in the South China Sea have become depleted over time. It is reported that some waters of the South China Sea have less than onetenth of fish stocks they had six decades ago. ${ }^{71}$ Most of the small pelagic species are already fully exploited. ${ }^{72}$

The South China Sea is presently under the strong pressure of overfishing and resources depletion, the coastal states surrounding it, therefore, need to take effective measures to ensure that the fish stocks are managed in a sustainable manner. Since most of the economic fish stocks in the South China Sea are shared or straddling stocks, cooperation between the countries is inevitable and urgent. It has been suggested that to set aside the sovereignty claims and focus on joint development and management of the natural resources is the best approach to managing the territorial disputes in the South China Sea. ${ }^{73}$ As the biggest bordering state, China generated serious concerns to cooperate on fishery management. There is no multilateral agreement or regional fisheries management organization in the South China Sea, and China's practice on cooperative management for the shared stocks mainly relies on bilateral arrangements.

China and Vietnam signed the Agreement on the Delimitation of the Territorial Seas, Exclusive Economic Zones and Continental Shelves in the Beibu Gulf and the Agreement on Fishery Cooperation in the Beibu Gulf (Sino-Vietnamese Fishery Agreement) in $2000 .{ }^{74}$ Both came into force in June 2004. These two agreements

\footnotetext{
${ }^{70}$ J.E. Randall, K.P. Lim, 'A Checklist of the Fishes of the South China Sea', The Raffles Bulletin of Zoology, Supplement No. 8, 2000, pp.569-667.

${ }^{71}$ R. Bale, 'One of the World's Biggest Fisheries Is on the Verge of Collapse: Major disputes in the South China Sea are putting critical habitat - and the food supply of millions-at risk', available at https://www.nationalgeographic.com/news/2016/08/wildlife-south-china-sea-overfishing-threatens-collapse/, last accessed 25 December 2019.

${ }^{72}$ See D. Rosenberg, 'Fisheries Management in the South China Sea', in S. Bateman, and R. Emmers (eds), Security and International Politics in the South China Sea: Towards a Cooperative Management Regime, Routledge Abingdon, 2009, p.30.

${ }^{73}$ I. Storey, Arctic Lessons: What the South China Sea Claimants can Learn from Cooperation in the High North, ISEAS, Singapore, 2013.p.23.

${ }^{74}$ An unofficial English text of the Fishery Agreement is available at Keyuan Zou, 'Sino-Vietnamese Fishery
} 
provide a legal framework for the conservation and management of fishery resources in Beibu (Tonkin) Gulf and create a cooperative mechanism to manage shared fishery resources.

A Common Fishery Zone (CFZ), a transitional agreement zone and a buffer zone for small fishing boats were established under the Sino-Vietnamese Fishery Agreement, within which different management measures were applied. The CFZ plays a vital role for managing shared stocks, as it is located in the EEZ of the two sides (See Figure 3), with the area of 30,000 square kilometers, covering most of the high productive fishing grounds. ${ }^{75}$ In the CFZ, the two sides should undertake long-term fisheries cooperation and jointly take measures to manage and maintain sustainable utilization of the living resources. ${ }^{76}$ China and Vietnam can formulate and apply domestic laws to their own side of the CFZ. Fishing boats from both sides must abide by the regulations if they intend to enter into the CFZ for fishing. When they intend to fish in the other party's CFZ, a special permit is needed. In comparison with the PMZs established under the Sino-Japan/Sino-Korea Agreement, the CFZ is not only considerably larger, accounting for $27.9 \%$ of the Gulf's total, ${ }^{77}$ but also has stricter and more effective measures. For example, fishmen are required to report if they take refuge in other party's harbor due to bad weather or emergencies; ${ }^{78}$ it is prohibited to catch marine mammals or other endangered species, bycatch should be released to the sea immediately and the fishing methods such as the use of explosive, electricity and poison are prohibited. ${ }^{79}$

Figure 3: The Sino-Vietnamese Agreement on the Gulf of Tonkin

\footnotetext{
Agreement for the Gulf of Tonkin,' International Journal of Marine and Coastal Law, Vol.17, 2002: pp.127-148.

75 Keyuan Zou, 'The Sino-Vietnamese Agreement on Maritime Boundary Delimitation in the Gulf of Tonkin', Ocean Development \& International Law, Vol.36, 2005, p.16.

${ }^{76}$ Sino-Vietnamese Fishery Agreement, Articles 4 and 5.

${ }^{77}$ Yunjun Yu and Yongtong Mu, 'The new institutional arrangements for fisheries management in Beibu Gulf', Marine Policy, Vol.30, 2006, p.254.

${ }^{78}$ Sino-Vietnamese Fishery Agreement, Article 15.

${ }^{79}$ Regulations on Conservation and Management of Fishery Resources in the Common Fishery Zone in Beibu Gulf, Article 20.
} 


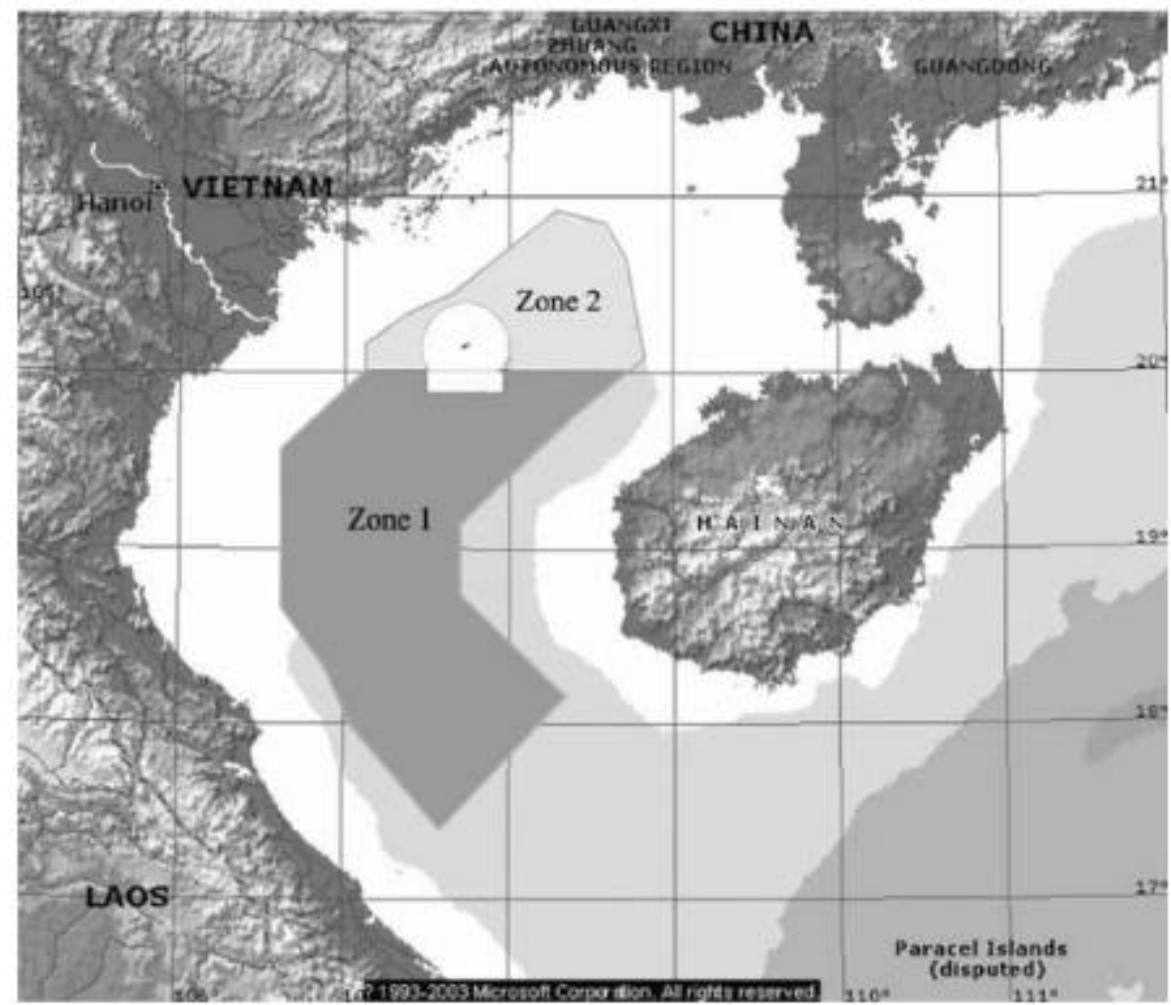

Source: Yunjun Yu and Yongtong Mu, 'The new institutional arrangements for fisheries management in Beibu Gulf', Marine Policy, Vol.30, 2006, p.251.

Note: Zone 1 stands for the Common Fishery Zone while Zone 2 stands for the Transitional Agreement Zone.

The special regulations and measures applied to CFZ and the number of vessels of each party entering into the CFZ are determined by the Joint Fishery Committee (JFC), an institutional mechanism established in accordance with the Fishery Agreement. It has a wide range of powers in handling all the issues in relation to the bilateral cooperation. ${ }^{80}$ Compared to the JFC of Sino-Japan/Sino-Korea Agreement, the JFC of the Sino-Vietnamese Fisheries Agreement has a broader mandate: it is authorized to deal with fisheries disputes occurring in the CFZ, which cannot be settled on the spot, ${ }^{81}$ while under the Sino-Japan/Sino-Korea Agreement, the JFC only has the right to make recommendations. To exercise its functions, the JFC has formulated the Regulations on Conservation and Management Fishery Resources in the Common Fishery Zone in

\footnotetext{
${ }^{80}$ Guifang Xue, 'Improved Fisheries Co-operation: Sino-Vietnamese Fisheries Agreement for the Gulf of Tonkin', International Journal of Marine and Coastal Law, Vol. 21, 2006, p.224.

${ }^{81}$ Sino-Vietnamese Fishery Agreement, Article 11.
} 
Beibu Gulf, which contains the detailed measures and legal liabilities for violation, giving a clear guidance to the nationals of both parties.

To avoid any conflict that may arise in the fishery cooperation, the transitional agreement zone with a four-year term was designated with the aim to leave time for the Chinese fishermen to adjust their fishing patterns. ${ }^{82}$ In order to avoid unnecessary disputes by illegal entry by mistake to the other party's territorial sea, the buffer zone for small fishing boats is set up in the territorial sea of both contracting parties. The small fishing boats refer to the boats that the length is less than $15 \mathrm{~m}$ or no more than $60 \mathrm{HP}$, when it is found in the buffer zone of the other party, it can be warned or driven away from that area by the other party. ${ }^{83}$ However, when doing do, resort to force or imposing punishment is not allowed and the boats in question should not be detained or arrested. ${ }^{84}$ Any dispute related to fishing activities shall be reported to the JFC for settlement.

Although the conservation of shared stocks of the South China Sea calls for the cooperation of all relevant states, and any bilateral arrangement is not enough, the institutions established under the bilateral fishery agreements can serve as an example for a multilateral agreement for the conservation of South China Sea fisheries. The Sino-Vietnamese Fisheries Agreement marked a new phrase of joint management of shared fish stocks since it is a long-term cooperation based on the demarcated maritime boundaries. On 30 June 2019, the Sino-Vietnamese Fisheries Agreement was expired. Before the new agreement is concluded, the two parties will continually implement the previous agreement. However, it is still uncertain that whether the new agreement will retain such a large CFZ in the Gulf of Tokin.

In addition to Vietnam, China has strengthened fishery cooperation with Indonesia and Malaysia in recent years. In 2013, the Ministry of Agriculture of China and the Marine Affairs and Fisheries Ministry of Indonesia signed a Memorandum of Understanding on Fisheries. According to the MOU, fisheries cooperation of various

\footnotetext{
${ }^{82}$ Keyuan Zou, 'The Sino-Vietnamese Agreement on Maritime Boundary Delimitation in the Gulf of Tonkin', Ocean Development \& International Law, Vol.36, 2005, p.16.

${ }^{83}$ See supera note 76, p. 255.

${ }^{84}$ Sino-Vietnamese Fishery Agreement, Article 12.
} 
forms would be undertaken to combat IUU fishing, promote data and information exchange, conserve fishery resources, and develop sustainable capture fisheries technical. ${ }^{85}$ In the following year, another MOU regarding the implementation arrangements for cooperation in capture fisheries was signed to develop a new form of cooperation in capture fisheries. ${ }^{86}$ Under the new arrangement, Chinese enterprises can cooperate by setting up joint venture in Indonesia, however, the cooperation of both enterprises and fishing boats shall be approved by the authorized departments of both parties and the total tonnage of cooperative fishing boats shall be limited to 100-500 tons. ${ }^{87}$

China's fishery cooperation with Malaysia is mainly reflected in fishery technical cooperation. China and Malaysia have signed three documents to enhance the marine technical operation. In 2017, China and Malaysia jointly formulated an Action Plan to increase cooperation in marine science and technology. ${ }^{88}$ The goals of this plan are to promote improve the research capacities of both sides and promote information and technology transfer between the research organizations. With this plan, the cooperation in marine observation, utilization of marine living resources and marine spatial planning would be enhanced. Marine scientific cooperation between China and Malaysia can be traced back to the year of 2009 when the two parties signed the Agreement on Marine Science and Technology Cooperation. ${ }^{89}$ After nearly a decade of efforts, a number of bilateral cooperation mechanism have been established, such as the Joint Committee on Cooperation in Marine Science and Technology and a joint Oceanographic Research Center. These cooperation mechanisms have positive significance to promote the fisheries cooperation.

Despite the bilateral cooperation with the neighboring states, China also take various fishery conservation measures in the South China Sea to ensure the sustainability of fishery resources, and the most important one is the summer fishing ban. China has

\footnotetext{
${ }^{85}$ See https://en.tempo.co/read/518856/ministry-signs-mou-on-fishery-with-china, last accessed 20 December 2019

${ }^{86}$ See www.moa.gov.cn/nybgb/2014/shiyi/201712/t20171219 6111606.htm, last accessed 20 December 2019.

${ }^{87}$ See www.shuichan.cc/news_view-220280.html, last accessed 20 December 2019.

${ }^{88}$ See www.fio.org.cn/news/7989.htm, last accessed 25 December 2019.

${ }^{89}$ See www.mnr.gov.cn/zt/hy/gihyj21sczl/gzbs/201705/t20170515 2102786.html, last accessed 25 December 2019.
} 
implemented the summer fishing ban since 1999, and the fishing ban lasts for two or three months, usually from May to August. ${ }^{90}$ The ban applies to the area north to 12 degrees northern latitude of the South China Sea. ${ }^{91}$ In 2012, China expended the covering area of the fishing ban, including Huangyan Island (Scaborough Shoal) but excluding most of the Nansha Islands. ${ }^{92}$ During the time of ban, all net fishing is closed and all waters under the ban is monitored 24 hours a day. ${ }^{93}$ Any violation will be handled in time and different penalties will be imposed according to the types of violation. Usually, fishing in the closed seasons will be imposed a fine of less than 5,0000 yuan, but in serious cases, fishing gears may be confiscated and fishing license may be revoked. ${ }^{94}$ Due to the depletion of the fish stocks, the closed season for all operating types has been prolonged from 2-3.5 months to 4.5 months. ${ }^{95}$ Although China's summer fishing ban in the South China Sea is challenged by Vietnam and the Philippines that have seen it as a violation of their jurisdictions over EEZ, it is undeniable that the fishing ban has a long-time positive effect on the prevention of overfishing and conservation of fish stocks.

\section{China's Practice on Distant Water Fisheries}

Because of the migratory characteristics of fish, the fish stocks might be exploited by several fishing nations, thus, the conservation of transboundary fisheries cannot be achieved by individual states, and international cooperation is inevitable. The RFMOs play a unique role in promoting the conservation and management of straddling and highly migratory fish stocks by adopting material and procedural principles and specific conservation measures. China is now a member of seven RFMOs, which include the

\footnotetext{
${ }^{90}$ Hai Dang Vu, 'A Bilateral Network of Marine Protected Areas Between Vietnam and China: An Alternative to the Chinese Unilateral Fishing Ban in the South China Sea?' Ocean Development \& International Law, Vol.44, p.146.

${ }_{91}$ 'China to impose fishing ban in South China Sea', Xinhua News, 17 May 2012, available at en.people.cn/102774/7819400.html, last accessed 25 December 2019.

${ }_{92}$ 'China impose routine fishing ban in South China Sea', Xinhua News, 16 May 2012, available at news.cntv.cn/20120516/112660_1.shtml, last accessed 25 December 2019.

${ }_{93}$ 'China imposes summer fishing ban', Xinhua News, 1 May 2019, available at www.chinadaily.com.cn/a/201905/01/WS5cc9054fa3104842260b972d.html, last accessed 25 December 2019.

${ }^{94}$ Fisheries Law, Article 38.

${ }^{95}$ Shuolin Huang and Yuru He, 'Management of China's capture fisheries: Review and prospect', Aquaculture and Fisheries, Vol. 4, 2019, p.178.
} 
International Commission for the Conservation of Atlantic Tunas (ICCAT), Indian Ocean Tuna Commission (IOTC), Western and Central Pacific Fisheries Commission (WCPFC), Inter-American Tropical Tuna Commission (IATTC), South Pacific Regional Fisheries Management Organization ( SPRFMO), North Pacific Fisheries Commission ( NPFC) and Commission for the Conservation of Antarctic Marine Living resources (CCAMLR). ${ }^{96}$

The management principles and strategies adopted by the above RFMOs have great impact on China's distant water fisheries (DWF). After joining the RFMOs, China did lots of efforts in controlling distant water fisheries to comply with the international standards requested by the RFMOs. Those efforts include adjusting policy and regulations, implementing various measures and deterring IUU fishing.

\section{(1) Adjustment of Policy and Regulations}

Since 2007, the concept of ecological civilization was first proposed at the $17^{\text {th }}$ National Congress, after then, "construction of ecological civilization" became a guiding principle for environmental laws, ${ }^{97}$ and it also has great impact on China's strategy of DFW. In March 2016, China's $13^{\text {th }}$ Five-Year Plan was released, in which the ecological civilization was one of the priorities, and in November 2017, the Ministry of Agriculture issued the $13^{\text {th }}$ Five-Year Plan of National Distant Water Fisheries Development (2016-2020), ${ }^{98}$ with the aim to strengthen standardized management and promote orderly development of DFW. The new plan sets up specific objectives for DWF, which include putting ceilings on the total number of vessels and reducing the number of DFW enterprises. It is stated that by 2020 , the total number of vessels will have been reduced to less than 3000 , and the number of companies involved in China's DWF fleet will remain frozen at the 2016 level. It is reported that there are 161 DWF

\footnotetext{
${ }_{96}$ See ocean.china.com.cn/2017-02/21/content_40327610.htm, last accessed 25 December 2019.

${ }^{97}$ The construction of ecological civilization was incorporated in the Constitution of the Communist Party in the 18th Nation Congress of the CPC in 2012. See cpc.people.com.cn/18/n/2012/1114/c350824-19582349.html.

${ }_{98}$ 'Ministry of Agriculture issued 13th Five-Year Plan of National Distant Water Fisheries Development', 8 December 2017, available at www.gov.cn/xinwen/2017-12/08/content 5245275.htm, lasted accessed 25 December 2019.
} 
enterprises in $2016 .{ }^{99}$ It is no doubt that the new plan will further reform the strategy of China's DWF and have positive impact on the management of straddling and highly migratory fish stocks.

In order to comply with international standards requested by RFMOs. China has also developed a series of regulations on DWF. China implemented fishing license system on DWF. According to Article 23 of the Fisheries Law, fishing operations on jurisdictional seas of other countries or in the jointly managed fishery zones defined in the agreements between China and the relevant countries or on the high sea shall obtain fishing licenses from the fishery administrative department of the State Council. ${ }^{100} \mathrm{~A}$ fishing license may be issued to the application only if he fulfills the following conditions: (1) has the fishing vessel inspection certificate; (2) has the fishing vessel registration certificate; (3)fulfills other conditions stipulated by the department in charge of fishery administration of the State Council. ${ }^{101}$ To better implement the provisions, the Ministry of Agriculture issued the Regulations on Distant Water Fisheries in 2003 and it was amended in 2016. ${ }^{102}$ According to the Regulations, the MOA shall adopt a system on the approval and administration of projects as well as on the accreditation of enterprise qualification to pelagic fishery and shall supervise and administer DWF vessels and seamen in accordance with the law. ${ }^{103}$ Vessels engaged in high sea fishing shall obtain a "license for fishing on the high sea" with the approval of MOA, ${ }^{104}$ and all authorised fishing vessels shall fly China's flag, ${ }^{105}$ complete fishing $\operatorname{logbooks}{ }^{106}$ and report the date of entry or exit, quantity of fishery captures, main species, production value and other information required by RFMOs. ${ }^{107}$ In order to better implement supervision, all fishing vessels are required to install the vessel

\footnotetext{
${ }^{99}$ Ye Chen and Haoyue Dai, 'The development history and characteristics of China's distant water fisheries' (in Chinese ), Ocean Development and Management, Vol.3, 2019, p.90.

${ }^{100}$ Fisheries Law, article 23.

${ }^{101}$ Fisheries Law, article 24

${ }^{102}$ The revised version of 2016 is available at www.gd.gov.cn/zwgk/zcfgk/content/post 2724327.html, last accessed 26 December 2017.

${ }^{103}$ Regulations on Distant Water Fisheries, Article 4.

${ }^{104}$ Regulations on Distant Water Fisheries, Article 9.

${ }^{105}$ Regulations on Distant Water Fisheries, Article 19.

${ }^{106}$ Regulations on Distant Water Fisheries, Article 20.

${ }^{107}$ Regulations on Distant Water Fisheries, Article 12.
} 
monitoring system (VMS) and equip crews with qualified technical training certificates to ensure the normal operation of the system and provide accurate information. ${ }^{108}$ Observers may be placed on board according to the requirements of relevant international organization. ${ }^{109}$

In order to further strengthen the management of DWF and adapt to the new changes and requirements of international fisheries management, the MOA also revised the Measures for the Monitoring and Management of Pelagic Fishing Vessels in 2014, ${ }^{110}$ which requires that automatic daily reporting of position by MVS shall not be less than 6 times a day, once every four hours. ${ }^{111}$ Those who move, dismantle or has closed the MVS without authorization or intentionally provide false report or alter the registration information of fishing vessels would be deduct the subsidies. ${ }^{112}$ In 2016, MOA issued the Rules for the Implementation of the Management of Observers to further promote the standardization, institutionalization and procedural work of observers. ${ }^{113}$ Both VMS and the observer measures are important management measures adopted by tuna RFMOs, the above regulations reflect that China has endeavored to regulate its DFW in line with the requirement of international arrangements.

\section{(2) Implementation of Conservation Measures}

The RFMOs has developed various effective measures to combat the problem of decreasing fisheries resource and promote international cooperation of management of highly migratory species. China as a member of four tuna RFMOs has taken steps to implement the conservation measures adopted by the tuna RFMOs.

Total allowable catch (TAC) is a usefully mechanism to ensure the long-time sustainability of the tuna species, and the tuna RFMOs has developed an extensive set

\footnotetext{
${ }^{108}$ Regulations on Distant Water Fisheries, Article 26.

${ }^{109}$ Regulations on Distant Water Fisheries, Article 26.

${ }^{110}$ See www.gov.cn/xinwen/2019-08/19/content_5422285.htm, last accessed 25 December 2016.

${ }^{111}$ Measures for the Monitoring and Management of Pelagic Fishing Vessels was first issued by MOA in 2012, in which daily automatic reporting of ship position information shall not be less than twice a day.

${ }^{112}$ Measures for the Monitoring and Management of Pelagic Fishing Vessels, Article 24.

${ }^{113}$ The text is available at zsoaf.zhoushan.gov.cn/art/2017/3/14/art_1563874_25965714.html, last accessed 25 December 2019.
} 
of criteria to allocation schemes. In setting a TAC, whether that TAC is based on a multispecies quota or an individual fish stock quota, adequate data and scientific analysis is most crucial. In order to implement the TAC measures and provide the best scientific advance and the accurate catch data, the MOA stipulated the standardized logbook of tuna. National observers have been placed on board the tuna longline and large trawl vessels, to collect date. The China Distance Water Fisheries Association was established in 2012 with the aim to assistant implementation of management measures by carry out information exchange and technical training. All Chinese enterprises fishing in the high sea are members of China Distance Water Fisheries Association. To promote the international cooperation in catch data, seven implementation teams have been established in accordance with the seven RFMOs which China is a member of, to participate the regular meeting of the RFMOs and exchange views on fishery data and scientific research.

To comply with the specific trade measures taken by ICCAT, IOTC and IATT to deter IUU fishing. China started to implement the Catch Certification Scheme in 2010, which requires inspection of imported products according to customs codes of imported species. ${ }^{114}$ According to the Joint Announcement of the General Administration of Customs and the MOA(No.1696), ${ }^{115}$ the customs clearance certificates are required when bigeye tuna, sword fish, bluefin tuna and toothfish entering China. For the abovementioned fish species caught by Chinese fishing vessels that transported back to China, the customs clearance certificates are also required. In 2014, another Joint Announcement was issued to apply customs clearance certificates for legal fishing products to certain aquatic products imported from Russia. ${ }^{116}$ The catch certificate scheme combined the market access control with the marine fisheries management, and

\footnotetext{
${ }^{114}$ Announcement No. 1389[2010] of the Ministry of agriculture and the General Administration of Customs on the implementation of the customs clearance certificate for legal fishing products for some imported aquatic products, the text is available at https://www.customslawyer.cn/portal/fgk/detail/id/43015.html, last accessed 25 December 2019.

${ }^{115}$ See www.lyg.gov.cn/zglygzfmhwz/nyfg/content/747AC923341D427A9A552E6FF338D38A.html, last accessed 25 December 2019.

${ }^{116}$ Joint Announcement No. 2146 [2014], General Administration of Customs and the Ministry of Agriculture Announcement on Deciding to Apply the Customs Clearance Certificates for Legal Fishing Products to Certain Aquatic Products Imported from Russia
} 
effectively promote the long-time sustainability of the highly migratory fish stocks, especially the tuna species.

\section{(3) Address IUU Fishing}

IUU fishing is a long-time challenge that threaten the sustainability of transboundary fisheries, and the conservation measures adopted by the RFMOs could be greatly weakened by IUU fishing. As the world's largest DWF nation, China also faces the challenge to tackle IUU fishing. In recently years, China has intensified its efforts to address the problem. The MOA has established a blacklist system for pelagic fishery enterprises, ${ }^{117}$ and it was announced that 15 people had been blacklisted, including six people whose enterprise licenses have been canceled and nine captains whose certificates have been withdrawn. ${ }^{118}$ The persons in the blacklist will be banned from working for a period time. In 2018, the MOA, for the first time, published a list of DWF companies and vessels that were penalised during the previous year. The penalties include cancellation of fuel subsidies or fishing licenses, and a five-year fishing ban on designated captains and crews. In order to prevent illegal fishing products from entering the market, the government also plans to create 10 fishing port clusters by 2025 with upgraded technology to better collect data on catches. ${ }^{119}$ Besides domestic efforts, China also take steps to cooperate with others to cracking down on IUU fishing. In July 2018, China and EU signed the Declaration on the establishment of a Blue Partnership for the Ocean, ${ }^{120}$ and it provides that the two sides will promote the initiatives of the FAO and of relevant RFMOs aiming at fighting IUU fishing activities and exchange information to suspected fishing vessels and conduct follow-up cooperation. ${ }^{121}$

\footnotetext{
${ }^{117}$ See www.moa.gov.cn/govpublic/YYJ/201701/t20170122 5462231.htm.

118 'General Office of the Ministry of Agriculture issued the Notification of illegal fishing vessel and handling opinions', 20 March 2018, available at www.moa.gov.cn/nybgb/2018/201803/201805/t20180528_6143244.htm, last accessed 25 December 2019.

${ }^{119}$ See www.moa.gov.cn/gk/ghjh_1/201805/t20180503 6141333.htm, last accessed 25 December 2019

${ }^{120}$ Declaration on the establishment of a Blue Partnership for the Oceans: towards better ocean governance, sustainable fisheries and a thriving maritime economy between the European Union and the People's Republic of China, available at ec.europa.eu/newsroom/mare/document.cfm?doc_id=53843, last accessed 25 December 2019 ${ }^{121}$ Ibid, p.5.
} 


\section{Conclusion}

The LOSC divides the ocean space into different jurisdictions, but the ocean space is closed interrelated. The governance of transboundary fisheries has long been of challenge to states. The complicated political and geographic characteristics of the seas surrounding China make the management of transboundary extremely difficult. Although China has signed bilateral fisheries agreement with Japan, Korea and Vietnam and improved cooperative management for shared stocks by the joint management in the PMZs, little effort has been done with the migratory species. It is suggested that China facilitate cooperation with neighboring coastal states to manage the transboundary fish stocks. The current fishery arrangement in the East China Sea and Yellow Sea is vulnerable and fisheries conflict is a threat to maritime security. The best way to prevent incidents is to encourage multilateral cooperation between China, Japan and Korea. China's fisheries management in the South China is much more difficult due to the overlapping claims of sovereignty. However, over the past 20 years, the fish stocks and catch rates of the South China Sea have been dramatically declined, ${ }^{122}$ and fisheries cooperation requires no delay. To promote fisheries cooperation, there are two options: to create a RFMO for the management of fisheries or to establish a marine protected area in the South China Sea. China is now a member of seven RFMOs, which reflects China's positive and cooperative attitude on the management of highly migratory species. Although China has taken steps to comply with the international standards and requirements, it still has much to do in future.

\footnotetext{
${ }^{122}$ South China Sea expert working group,' A blueprint for fisheries management and environmental cooperation in the South China Sea,' 13 September 2017, available at https://amti.csis.org/coc-blueprint-fisheries-environment/, last accessed 25 December 2019.
} 